\title{
Impact of cypermethrin on blood profile, tissue redox parameters and the observation of histopathological changes in the liver of Rabbit (Oryctolagus cuniculus)
}

\author{
Farzeen Saeed ${ }^{1 *}$ and Razia Iqbal ${ }^{1}$ \\ 1. Department of Zoology, University of Gujrat, Punjab, Pakistan \\ *Corresponding author's email: saeed.frzn@gmail.com \\ Citation
}

Farzeen Saeed and Razia Iqbal. Impact of cypermethrin on blood profile, tissue redox parameters and the observation of histopathological changes in the liver of Rabbit (Oryctolagus cuniculus). Pure and Applied Biology. Vol. 11, Issue 2, pp468-482. http://dx.doi.org/10.19045/bspab.2022.110046

\begin{tabular}{llll}
\hline \hline Received: 03/05/2021 & Revised: 16/07/2021 & Accepted: 27/07/2021 & Online First: 26/08/2021 \\
\hline
\end{tabular}

\section{Abstract}

The present study was conducted to examine the effects of Cypermethrin on the blood profile, tissue redox parameters and the histopathological changes in the liver of rabbit. 36 male rabbits were randomly divided into three treatment groups and orally administered concentrations of Cypermethrin was provided to them per unit of body weight; Treatment group A; T1 $(300 \mathrm{mg} / \mathrm{kg})$, Treatment group B; T2 $(600 \mathrm{mg} / \mathrm{kg})$, Treatment group C; T3 $(900 \mathrm{mg} / \mathrm{kg})$ and group D; T0 (Control group). The blood profile of these rabbits showed that there was a noteworthy decrease in the $\mathrm{Hb}, \mathrm{RBCs}, \mathrm{Hct}, \mathrm{MCV}, \mathrm{MCH}$ and MCHC of the rabbits. The number of platelets and WBCS increased as the concentration of Cypermethrin increased. The catalase activity also increased in a dose dependent manner with the highest activity seen at the chemical concentration of $900 \mathrm{mg} / \mathrm{kg}$. Histopathological studies showed that Cypermethrin caused necrosis, congestion, vacuolization and tissue degeneration in the livers of almost all the treatment groups. On the basis of these results, it was concluded that Cypermethrin is not safe for animals, so finding alternatives to these pesticides is a prerequisite to prevent toxicity in animals and humans alike.

Keywords: Cypermethrin; Histopathological; Necrosis; Pyrethroids; Tissue redox; Toxicity

\section{Introduction}

Pesticides have not only been used to combat pests but have also played a major role in the amelioration of crop yields, worldwide. Pesticides have been devised to kill pests but a large amount of these pesticides and their residues become a part of non-targeted species and their environments, ultimately causing harm to their overall health [1].

Pyrethroids are the pesticides that have been synthetically produced belonging to two classes i.e. Type 1 and Type 2 which are set apart from one another on the basis of their chemical properties. Cypermethrin, a type 2 pyrethroid has shown incredible insecticidal properties making it one of the best agricultural pesticides [2]. It is a neurotoxin with a rapid activity rate to cause tissue redox damage [3]. Cypermethrin is sprayed on various crops to control insect pests of apple, pears, cabbage, cotton, oats, potatoes and wheat [4]. Cypermethrin has always been 
successful in protection of crops throughout the world. But studies conducted in the last few years have shown that it is recognized to negatively impact the non-targeted species including animals and humans, alike.

Cypermethrin enters the body via the inhalation of the chemical spray or by coming in direct contact with the skin. Being lipophilic in nature, it accumulates under the skin, in the liver, kidneys, ovaries and brain [5]. Being a neurotoxin Cypermethrin affects the central nervous system of the insects [6]. It makes the sodium channels open up and prolongs the depolarization of the cell membrane, directing the release of augmented levels of the neurotransmitters. The unending firing of the neurons and the emission of neurotransmitters ultimately causes their reduction. This depletion in turn decreases the activity of amino butyric acid receptor after subsequent convulsions and the body stays in a state of disordered CNS [7].

The most common symptoms of Cypermethrin exposure are dizziness, nausea, vomiting, fatigue, headache and abnormal facial sensations. Hematological, biochemical and physiological systems have been reported to be affected by this chemical [8].

Cypermethrin affects the kidneys by causing inflammation in the renal tubes, shrinkage of glomeruli, hemorrhage and disintegrated Bowman's capsule [9].

It affects the lungs by causing cellular deposition in the extracellular matrix and subsequent reduction in the alveolar pockets. Cypermethrin deposition also leads to hyperplasia, necrosis and pycnosis due to the destruction of alveolar cells and inflammation of lung tissues [10].

Cypermethrin also causes a drastic increase in the LPO production in fishes and boosts up the formation of Reactive Oxygen Species and modification of antioxidant or liberated oxygen. Radical hunting enzyme systems thereby deteriorate the redox parameters [11].

Keeping in mind, the neurotoxic properties of Cypermethrin and its effects in the body of animals, the current research work was designed to determine its effects on the blood profile, tissue redox parameters and histopathological changes in the liver of rabbit, Oryctolagus cuniculus.

\section{Materials and Methods}

\section{Selection and handling of animals}

36 male rabbits Oryctolagus cuniculus, weighing approximately $1.5 \mathrm{~kg}$, were chosen as the research animals. They were acquired from Ghazi Road, Lahore Institute of Veterinary Research Lahore, Punjab, Pakistan. The rabbits were kept in a Zoology lab under monitored conditions. Cleanliness and hygiene of the rabbits was thoroughly checked and animal waste was removed daily to prevent disease or stress in the rabbits. Light settings i.e. $12 \mathrm{~h}$ light/ dark cycles and temperature setting at 21 to $25^{\circ} \mathrm{C}$ with careful food and water provision three times a day [12].

\section{Dosage design}

The rabbits were separated into four groups on the basis of the Cypermethrin doses to be provided to them. They were Treatment group $T_{1} \quad(300 \mathrm{mg} / \mathrm{kg})$, Treatment group $\mathrm{T}_{2} \quad(600 \mathrm{mg} / \mathrm{kg})$, Treatment group $\mathrm{T}_{3}(900 \mathrm{mg} / \mathrm{kg})$ and Group D $\left(\mathrm{T}_{\mathrm{o}}\right)$ i.e. Control group. Each group consisted of 9 rabbits. These groups were treated in their separate enclosures in defined conditions. Moreover, doses were administered with the rabbit food, ad libitum.

To minimize the chances of mistakes or inaccuracy, three replications were made for each treatment were. The doses were given regularly to the groups for 44 days, early in the morning. On days 11, 22 and 44, samples were taken two hours after the supply of dose [13].

\section{Collection of blood samples}

To avoid stress while collecting blood samples, rabbits were handled carefully and in a calm way, since anxiety can affect the blood profile test. Blood was taken out of the jugular vein so the fur of the rabbit was initially shaved off and exposed region was washed with $70 \%$ isopropyl alcohol. 
The samples were then collected from the jugular vein of all rabbit groups $T_{1}, T_{2}, T_{3}$ and $\mathrm{T}_{\mathrm{o}}$. A $5 \mathrm{ml}$ syringe was attached to a butterfly catheter and then attached with an insulin syringe to collect samples in the EDTA tubes. Blood was taken carefully to avoid the blood cell breakdown in the syringe. Silver nitrate was used to stop the bleeding from the site [14].

\section{Hematological tests}

EDTA tubes containing EDTA anticoagulants were used for the performance of CBC (complete blood count). These tubes were shaken in order to prevent the chance of blood clotting. All samples were properly labeled. Semiautomatic Chemistry Analyzer (Labomed BAM-100 TS) were used to measure the CBC (Hb, RBCs, HCT, MCV, MCH, $\mathrm{MCHC}$, Platelets and WBCs) of rabbits. Samples were assessed after 24 hours for the best results.

\section{Tissue collection in rabbits for histopathological studies}

The rabbits were anesthetized using chloroform. Liver tissues were surgically removed and then thoroughly washed with water and dipped in 0.085 saline solution for the elimination of traces of blood [15]. Organs were then cut into tiny pieces to allow maximum saturation of the chemicals inside the tissue samples.

Histopathological method [16] was used to study the changes in the liver samples of rabbits. The tissue was fixed by dipping in Bouin's fixative for 17 hours and then washed with tap water for an hour to allow the removal of Bouin's fluid from the tissues. They were dehydrated in a series of ascending alcohol concentrations; 70\%, $90 \%$ and $100 \%$ for 15,15 and 30 minutes respectively. The tissues were then thoroughly washed with xylene. Blocks were made with paraffin wax and were mounted on Microtome (SHIBUYA by optical. Co LTD) to make $6 \mu \mathrm{m}$ sections of the tissues. Water, which had adhered to the tissue sections was removed by a $40^{\circ} \mathrm{C}$ water bath after which the sections were placed on slides and deparaffinized by washing with xylene. Dehydration in descending manner of alcohol grading was done and Haematoxylene blue and eosin yellow solutions were the selected stains for preparing permanent tissue slides. Coverslips were placed over the slide which were then observed at $\mathrm{x} 100$ magnification under Stereo Microscope with a digital camera (FRL Lx400), attached to the system and images were captured for future comparisons.

\section{Measurement of catalase activity}

Simple spectrophotometric method [17] was used to measure catalase activity at $550-\mathrm{nm}$ band due to the maximum absorbance on this wavelength (Table 1).

Table 1. Procedure for measurement of catalase activity

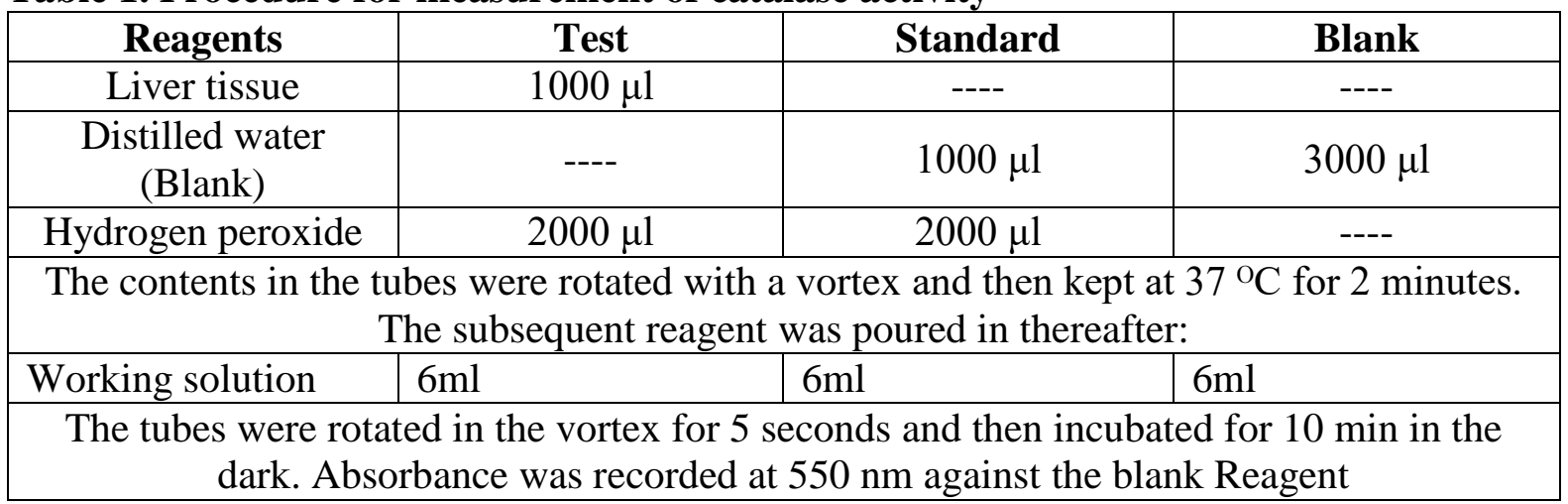

\section{Statistical analysis}

SPSS (Statistical Package for Social Science) 21 was used for the analysis of data. In addition, standard error means
$( \pm$ S.E.M $)$ was calculated. Additionally, variation among groups was determined by using ANOVA. 


\section{Results and Discussion}

The study revealed that Cypermethrin had a notable impact on the male rabbits. The outcome displayed that the hematological parameters including Red Blood Cells (RBCs), Hemoglobin (Hb), Hematocrit (HCT), Mean Corpuscular Volume (MCV), Mean Corpuscular Hemoglobin $(\mathrm{MCH})$ and Mean Corpuscular Hemoglobin Concentration (MCHC) declined in a dose dependent style. Red blood cells may be reduced due to the formation of hypoxic conditions as a result of Cypermethrin exposure. This could lead to increased rate of $\mathrm{RBC}$ destruction or a decreased rate of RBC formation. This reduction in the RBC formation could be a result of the non-availability of hemoglobin content in the cellular medium [18]. It is deduced from prior studies that HCT was minimized as a result of erythroblast and the levels of $\mathrm{MCV}$ and $\mathrm{Hb}$ declined due to microcytic anemia or hypoxic conditions. The reduction in hemoglobin level may be due to two reasons; either an increase in the hemoglobin destruction rate or a decrease in the hemoglobin synthesis rate [19]. Anemia could have been caused because of erythrocyte destruction, induced by seepage of Cypermethrin into the RBCs. So, reduced number of erythrocytes lower the levels of hemoglobin and hematocrit [20]. However, an increase in the Platelets and the White Blood cells showed that the natural immunity system of the rabbits was activated, trying to cope with the injury caused by the chemical.

Catalase is a crucial antioxidant enzyme which neutralizes hydrogen peroxide [21, 22]. Decreased concentration of purple disubstituted quinine complex in the present study was associated with an increased catalase activity. Highest peaks were formed at $550 \mathrm{~nm}$ due to the maximum absorbance. These peaks were used to measure the catalase activity. The increased catalase activity showed elevated oxidative stress in the rabbit liver samples as the concentration of the chemical increased.

The histopathological findings of liver samples of rabbits at days 11, 22 and 44 suggested that there was an increasing trend in the damage caused by Cypermethrin with increasing concentration. The maximum results were observed in doses $900 \mathrm{mg} / \mathrm{kg}$ at $11^{\text {th }}, 22^{\text {nd }}$ and $44^{\text {th }}$ days (Table 2).

Table 2. Effect of different dosage of cypermethrin on blood profile of rabbit at $11^{\text {th }}, \mathbf{2 2}^{\text {nd }}$ and $44^{\text {th }}$ day

\begin{tabular}{|c|c|c|c|c|c|}
\hline \multicolumn{6}{|c|}{ Concentration Used } \\
\hline Parameters & Duration & $\begin{array}{c}\text { T0 } \\
\text { Control }\end{array}$ & $\begin{array}{c}\text { T1 } \\
0.4 \mathrm{~g} / \mathrm{kg} \\
\text { BW }\end{array}$ & $\begin{array}{c}\text { T2 } \\
0.6 \mathrm{~g} / \mathrm{kg} \\
\mathrm{BW}\end{array}$ & $\begin{array}{c}\text { T3 } \\
0.7 \mathrm{~g} / \mathrm{kg} \\
\text { BW }\end{array}$ \\
\hline $\begin{array}{c}\text { WBCs } \\
(\mathrm{x} 103 / \mu \mathrm{l}) \\
\end{array}$ & & $10.50 \pm 0.05^{\mathrm{a}}$ & $11.00 \pm 0.11^{\mathrm{b}}$ & $11.76 \pm 0.08^{c}$ & $11.90 \pm 0.05^{\mathrm{c}}$ \\
\hline $\begin{array}{c}\text { RBCs } \\
(\mathrm{x} 103 / \mu \mathrm{l})\end{array}$ & & $5.90 \pm 0.01^{\mathrm{d}}$ & $5.45 \pm 0.01^{\mathrm{c}}$ & $5.40 \pm 0.01^{\mathrm{b}}$ & $4.26 \pm 0.01^{\mathrm{a}}$ \\
\hline $\mathrm{Hb}(\mathrm{g} / \mathrm{dL})$ & & $10.34 \pm 0.08^{\mathrm{d}}$ & $9.26 \pm 0.01^{\mathrm{c}}$ & $8.36 \pm 0.07^{b}$ & $8.22 \pm 0.12^{\mathrm{a}}$ \\
\hline $\mathrm{HCT}(\%)$ & & $48.93 \pm 0.14^{\mathrm{c}}$ & $42.50 \pm 0.20^{\mathrm{b}}$ & $42.10 \pm 0.5^{b}$ & $41.80 \pm 0.11^{\mathrm{a}}$ \\
\hline $\mathrm{MCV}(\mathrm{fL})$ & & $68.00 \pm 0.57^{\mathrm{c}}$ & $58.30 \pm 0.11^{\mathrm{b}}$ & $57.91 \pm 0.10^{\mathrm{b}}$ & $55.30 \pm 0.11^{\mathrm{a}}$ \\
\hline$\overline{\mathrm{MCH}(\mathrm{pg})}$ & & $24.03 \pm 0.88^{\mathrm{d}}$ & $21.50 \pm 0.28^{\mathrm{c}}$ & $20.00 \pm 0.28^{\mathrm{b}}$ & $18.50 \pm 0.28^{\mathrm{a}}$ \\
\hline $\begin{array}{l}\mathrm{MCHC} \\
(\mathrm{g} / \mathrm{dL})\end{array}$ & & $48.26 \pm 0.08^{\mathrm{d}}$ & $39.26 \pm 0.14^{c}$ & $36.60 \pm 0.11^{\mathrm{b}}$ & $31.00 \pm 0.11^{\mathrm{a}}$ \\
\hline $\begin{array}{l}\text { Platelets } \\
(\mathrm{x} 103 / \mu \mathrm{l})\end{array}$ & $\begin{array}{l}\text { 11th } \\
\text { Day }\end{array}$ & $335.0 \pm 2.88^{\mathrm{a}}$ & $360.00 \pm 5.77^{b}$ & $390.0 \pm 5.77^{\mathrm{c}}$ & $420.00 \pm 5.77^{\mathrm{d}}$ \\
\hline $\begin{array}{c}\text { WBCs } \\
(\mathrm{x} 103 / \mu \mathrm{l}) \\
\end{array}$ & & $10.50 \pm 0.05^{\mathrm{a}}$ & $11.80 \pm 0.11^{\mathrm{b}}$ & $12.40 \pm 0.11^{\mathrm{b}}$ & $12.53 \pm 0.20^{\mathrm{c}}$ \\
\hline RBCs & & $5.90 \pm 0.01^{\mathrm{d}}$ & $5.41 \pm 0.01^{\mathrm{c}}$ & $5.31 \pm 0.05^{\mathrm{b}}$ & $4.58 \pm 0.01^{\mathrm{a}}$ \\
\hline
\end{tabular}




\begin{tabular}{|c|c|c|c|c|c|}
\hline$(\mathrm{x} 103 / \mu \mathrm{l})$ & & & & & \\
\hline $\mathrm{Hb}(\mathrm{g} / \mathrm{dL})$ & & $48.93 \pm 0.14^{\mathrm{c}}$ & $41.95 \pm 0.02^{\mathrm{b}}$ & $41.88 \pm 0.01^{\mathrm{b}}$ & $41.40 \pm 0.11^{\mathrm{a}}$ \\
\hline HCT (\%) & & $36.21 \pm 0.57^{\mathrm{a}}$ & $37.77 \pm 0.61^{\mathrm{a}}$ & $38.07 \pm 0.89^{\mathrm{b}}$ & $39.67 \pm 0.04^{\mathrm{b}}$ \\
\hline MCV (fL) & & $68.00 \pm 0.57^{\mathrm{c}}$ & $58.00 \pm 0.05^{\mathrm{b}}$ & $57.30 \pm 0.11^{\mathrm{b}}$ & $54.80 \pm 0.05^{\mathrm{a}}$ \\
\hline$\underline{\mathrm{MCH}(\mathrm{pg})}$ & & $24.03 \pm 0.88^{\mathrm{d}}$ & $19.00 \pm 0.28^{\mathrm{c}}$ & $17.50 \pm 0.28^{\mathrm{b}}$ & $16.00 \pm 0.28^{\mathrm{a}}$ \\
\hline $\begin{array}{l}\mathrm{MCHC} \\
(\mathrm{g} / \mathrm{dL})\end{array}$ & & $48.26 \pm 0.08^{\mathrm{d}}$ & $38.73 \pm 0.08^{\mathrm{c}}$ & $33.20 \pm 0.05^{\mathrm{b}}$ & $27.60 \pm 0.05^{\mathrm{a}}$ \\
\hline Platelets & $\begin{array}{l}\text { 22th } \\
\text { Day }\end{array}$ & $335.0 \pm 2.88^{\mathrm{a}}$ & $400.00 \pm 5.77^{\mathrm{b}}$ & $430.0 \pm 5.77^{\mathrm{c}}$ & $460.0 \pm 5.77^{\mathrm{d}}$ \\
\hline $\begin{array}{c}\text { WBCs } \\
(\mathrm{x} 103 / \mu \mathrm{l})\end{array}$ & & $10.50 \pm 0.05^{\mathrm{a}}$ & $12.60 \pm 0.11^{\mathrm{b}}$ & $12.80 \pm 0.05^{\mathrm{c}}$ & $13.31 \pm 0.08^{c}$ \\
\hline $\begin{array}{c}\text { RBCs } \\
(\mathrm{x} 103 / \mu)\end{array}$ & & $5.90 \pm 0.01^{\mathrm{d}}$ & $5.39 \pm 0.01^{\mathrm{c}}$ & $4.91 \pm 0.04^{\mathrm{b}}$ & $4.45 \pm 0.05^{\mathrm{a}}$ \\
\hline $\mathrm{Hb}(\mathrm{g} / \mathrm{dL})$ & & $10.34 \pm 0.08^{\mathrm{d}}$ & $8.77 \pm 0.04^{\mathrm{c}}$ & $7.94 \pm 0.03^{b}$ & $7.20 \pm 0.11^{\mathrm{a}}$ \\
\hline HCT (\%) & & $48.93 \pm 0.14^{\mathrm{c}}$ & $41.70 \pm 0.05^{\mathrm{b}}$ & $41.71 \pm 0.01^{\mathrm{b}}$ & $40.96 \pm 0.13^{\mathrm{a}}$ \\
\hline$\overline{\mathrm{MCV} \text { (fL) }}$ & & $68.00 \pm 0.57^{\mathrm{c}}$ & $57.60 \pm 0.11^{\mathrm{b}}$ & $56.80 \pm 0.11^{\mathrm{b}}$ & $53.93 \pm 0.14^{\mathrm{a}}$ \\
\hline$\underline{\mathrm{MCH}(\mathrm{pg})}$ & & $24.03 \pm 0.88^{\mathrm{d}}$ & $17.50 \pm 0.28^{\mathrm{c}}$ & $16.00 \pm 0.28^{\mathrm{b}}$ & $14.50 \pm 0.28^{\mathrm{a}}$ \\
\hline $\begin{array}{l}\mathrm{MCHC} \\
(\mathrm{g} / \mathrm{dL})\end{array}$ & & $48.26 \pm 0.08^{\mathrm{d}}$ & $37.50 \pm 0.11^{\mathrm{c}}$ & $32.20 \pm 0.11^{\mathrm{b}}$ & $22.93 \pm 0.08^{\mathrm{a}}$ \\
\hline Platelets & $\begin{array}{l}\text { 44th } \\
\text { Day }\end{array}$ & $335.0 \pm 2.88^{\mathrm{a}}$ & $440.0 \pm 5.77^{\mathrm{b}}$ & $480.0 \pm 5.77^{\mathrm{c}}$ & $520.0 \pm 5.77^{\mathrm{d}}$ \\
\hline
\end{tabular}

The (Figs. 1-8) for hematological parameters exhibited a pronounced difference in the values expressed by the treatment groups in comparison to the control group. Statistical analysis also indicated that at different concentrations of Cypermethrin $(300,600$ and $900 \mathrm{mg} / \mathrm{kg}$ ) the values were lower than normal range. The maximum reduction was seen at $900 \mathrm{mg} / \mathrm{kg}$ at $44^{\text {th }}$ day with values Hemoglobin (7.20 \pm 0.11$), \quad$ RBCs $\quad(4.45 \pm 0.05), \quad$ HCT (40.96 \pm 0.13$), \mathrm{MCV}(53.93 \pm 0.14), \mathrm{MCH}$ $(14.50 \pm 0.28)$ and MCHC (22.93 \pm 0.08$)$ respectively. Platelets and the White Blood Cells increased in a dose dependent manner and were above the normal level in comparison with the control group with the mean values at $520.0 \pm 5.77$ and $13.31 \pm 0.08$ at $44^{\text {th }}$ day, respectively. The results suggested that maximum change was observed in treatment group $\mathrm{T} 3$ due to the highest concentration (i.e. $900 \mathrm{mg} / \mathrm{kg}$ ) of Cypermethrin administered to it. These findings were compatible with those of [23] who used Cypermethrin at concentrations 25,50 and $75 \mathrm{mg} / \mathrm{Kg}$ respectively. The results marked a reduction in $\mathrm{RBC}$ counts, the concentration of Hemoglobin and PCV in rabbits indicating that they were suffering from anemia. Similar results were reported by [19] who exposed Cyprinus carpio at $0.02 \mathrm{ppm}$ of Cypermethrin. They saw a decrease in RBC number and hemoglobin content, suggesting that pesticides have toxic effects on the erythropoietic tissue which result in the reduced viability of the cells. In another research performed by [24], studied the effects of cypermethrin $(24 \mathrm{mg} / \mathrm{kg}$ body weight) on male rabbits. Their results suggested that cypermethrin reduced hemoglobin $(\mathrm{Hb})$, packed cell volume (PCV) and total erythrocytic count (TEC). Furthermore, [25] reported that a diminution of $-5.8 \%$ in $\mathrm{Hb},-5.5 \%$ in $\mathrm{HCT}$ and $-0.5 \%$ in MCV level was seen in male rabbits after cypermethrin exposure. They suggested that both of these chemicals encouraged modifications in hematological indices and are proposed to be neurotoxic with leukemic predisposition for rabbits and other vertebrates including humans. 


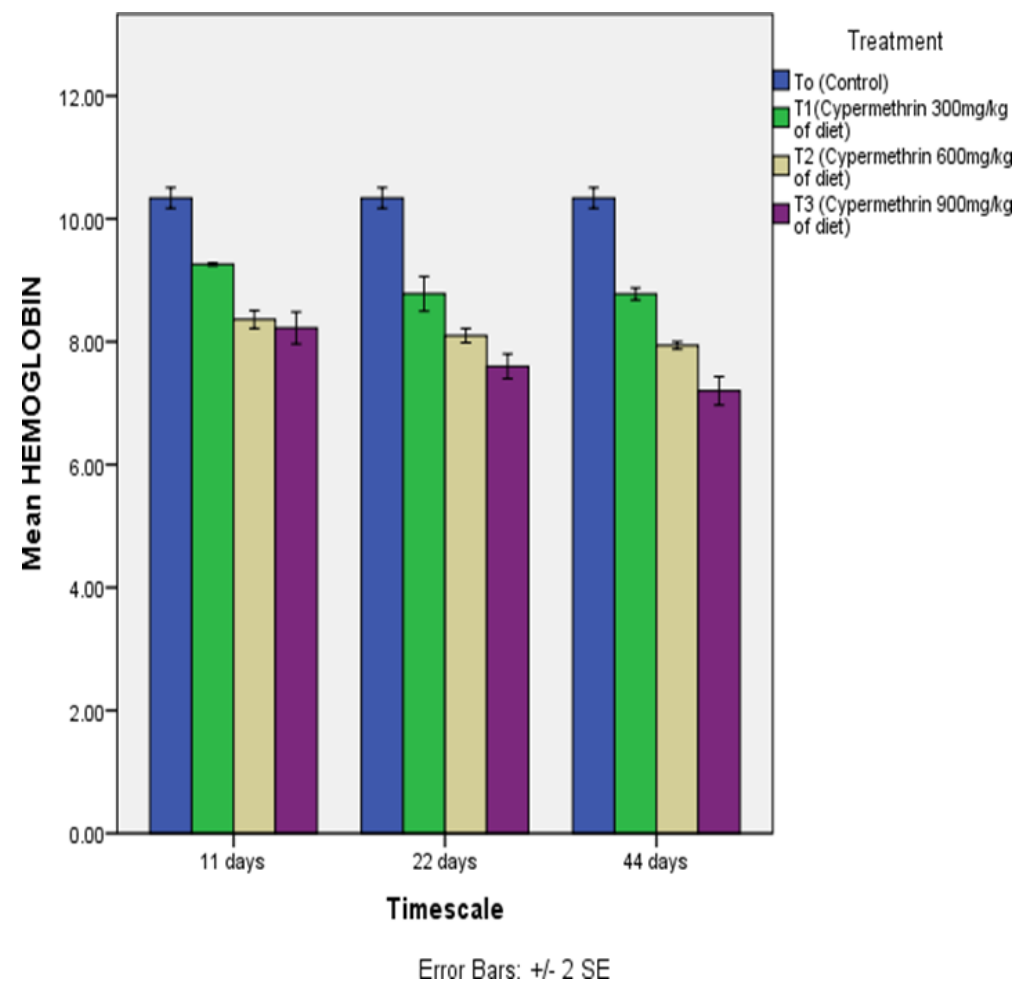

Figure 1. Effect of Cypermethrin on Hemoglobin of Rabbit at the Time Scale 11th, 22nd and 44th Day

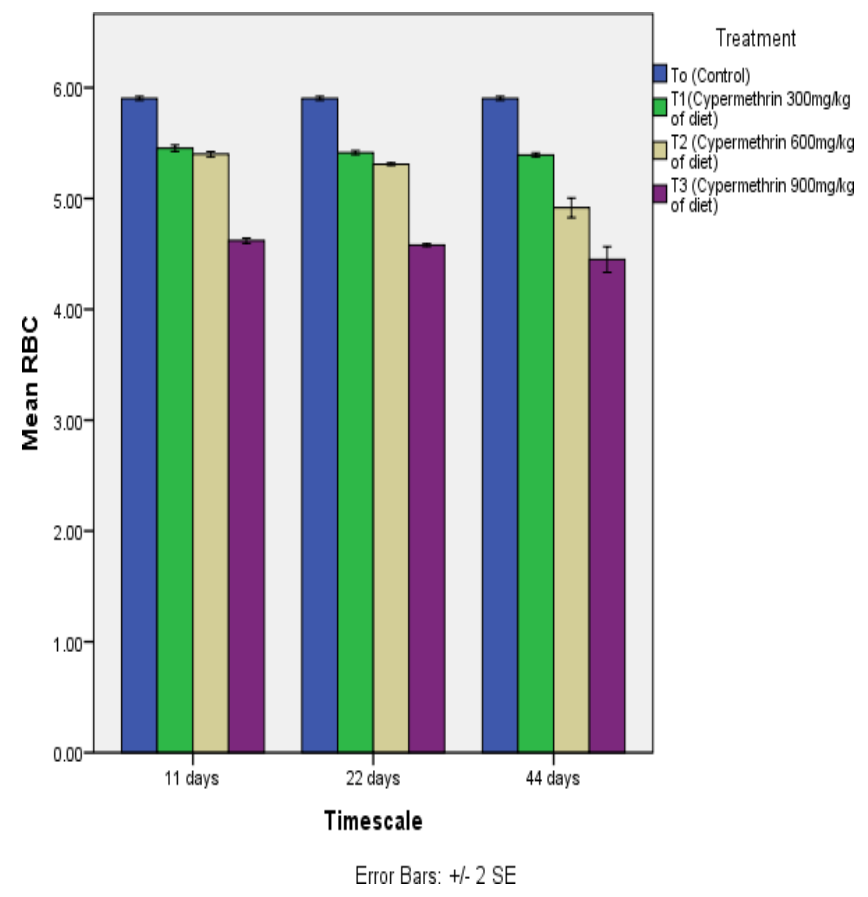

Figure 2. Effect of Cypermethrin on RBCs of Rabbit at the Time Scale of 11th, 22nd and 44th Day 


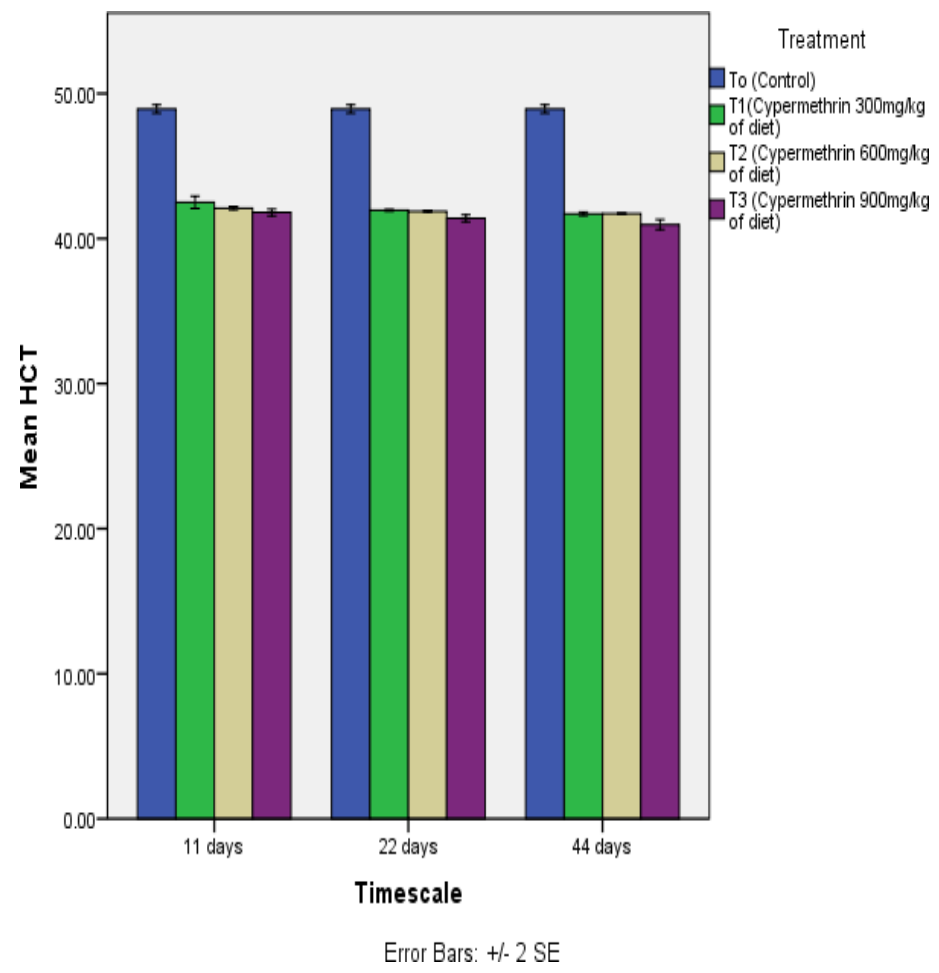

Figure 3. Effect of Cypermethrin on Hematocrit of Rabbit at the Time Scale of 11th, 22nd and 44th Day

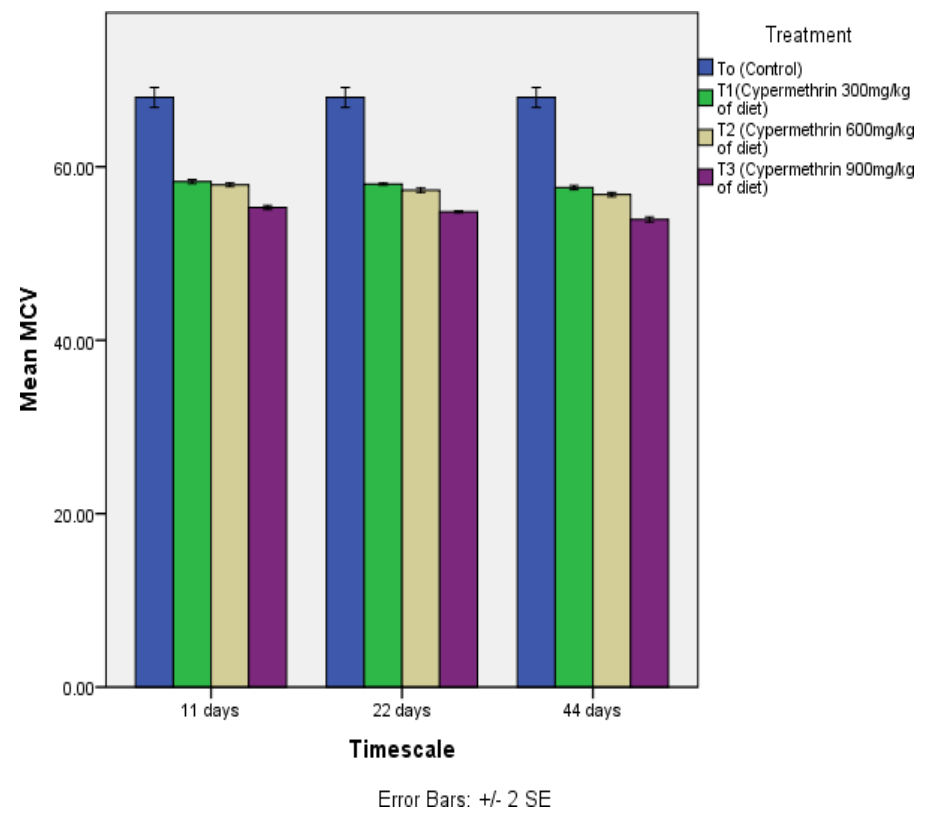

Figure 4. Effect of Cypermethrin on MCV of Rabbit at the Time Scale of 11th, 22nd and 44th Day 


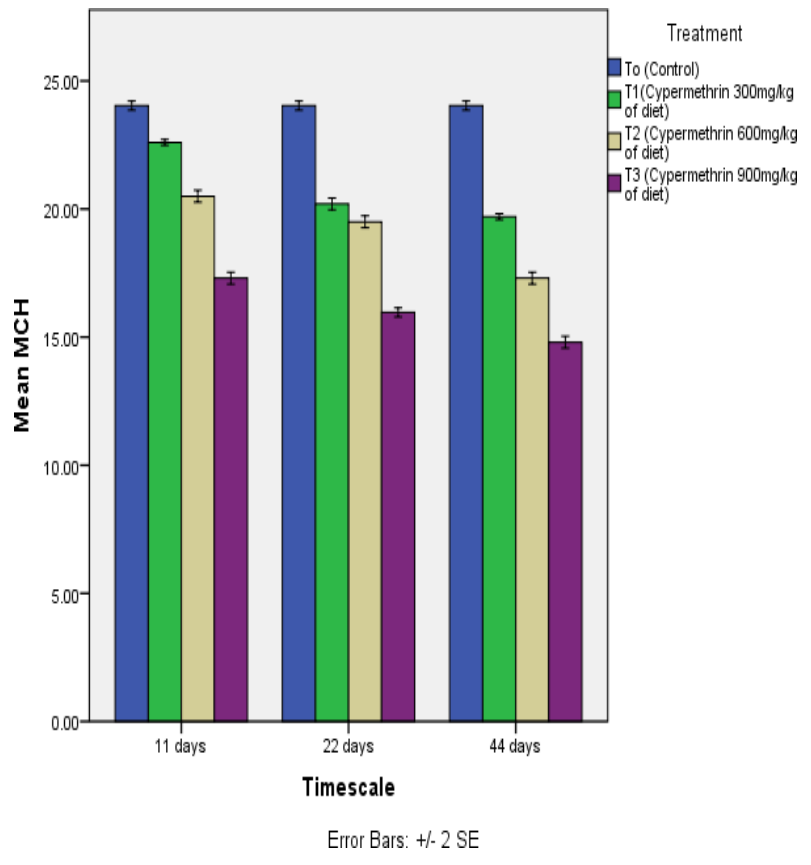

Figure 5. Effect of Cypermethrin on MCH of Rabbit at the Time Scale of 11th, 22nd and 44th Day

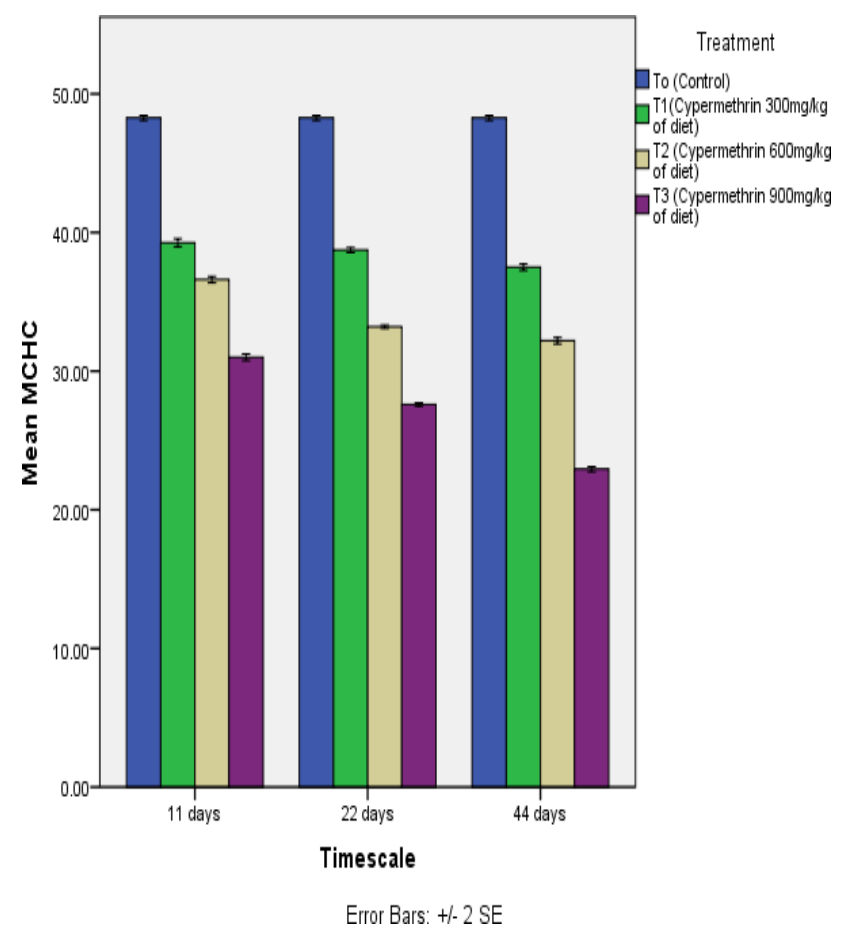

Figure 6. Effect of Cypermethrin on MCHC of Rabbit at the Time Scale of 11th, 22nd and 44th Day 


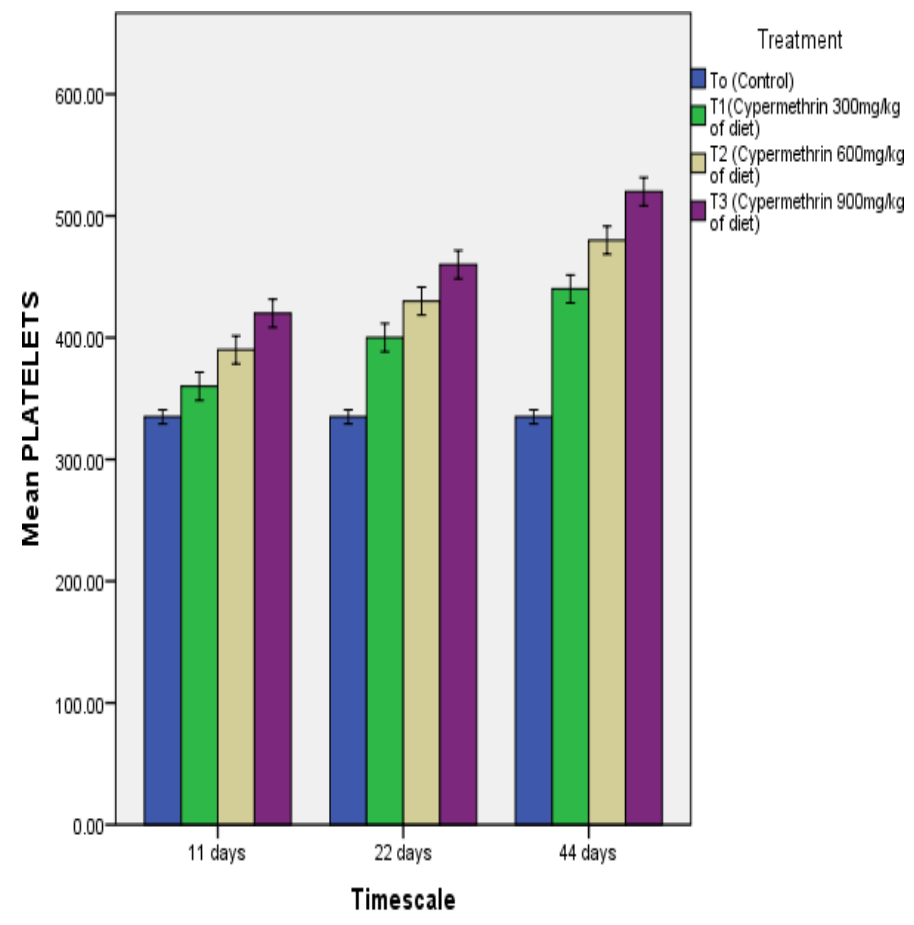

Error Bars: $+1-2$ SE

Figure 7. Effect of Cypermethrin on Platelets of Rabbit at the Time Scale of 11th, 22nd and 44th Day

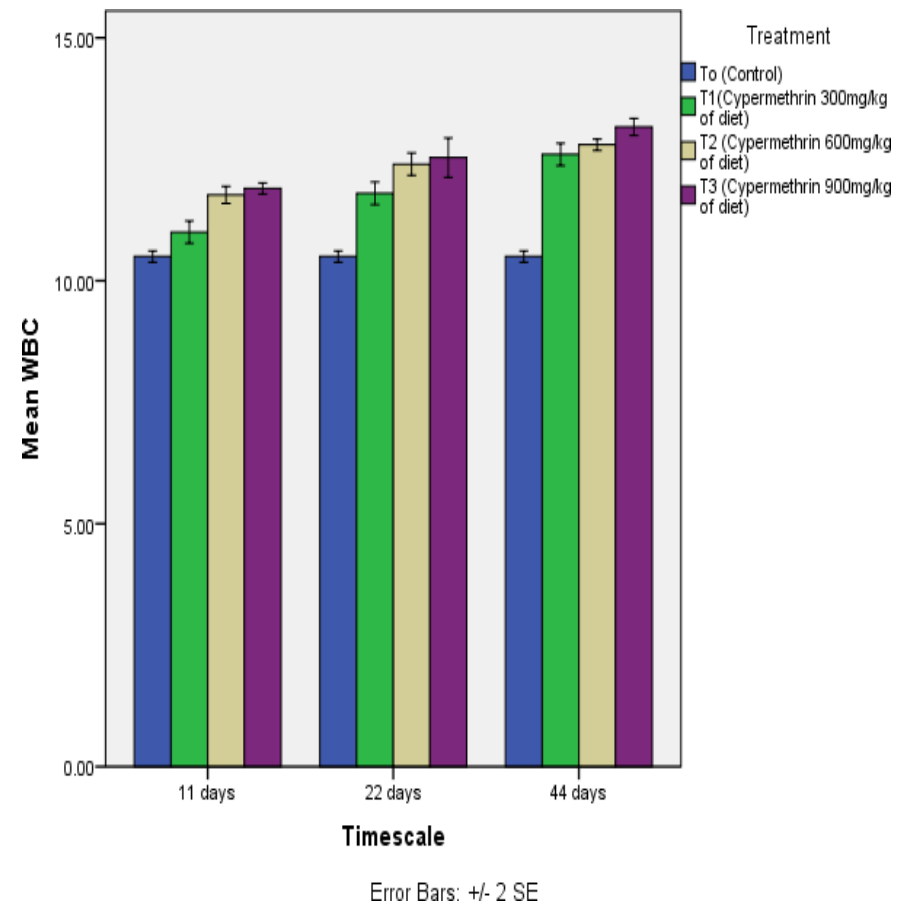

Figure 8. Effect of Cypermethrin on WBCs of Rabbit at the Time Scale of 11th, 22nd and 44th Day 
The (Figs. 9-12) clearly displayed that the catalase activity significantly increased in all the treatment groups in a dose dependent manner. However when the results of all the groups were compared, the treatment group $\mathrm{C}(\mathrm{T} 3)$ which was administered $900 \mathrm{mg} / \mathrm{kg}$ of Cypermethrin showed the highest value for catalase activity at days 11,22 and 44 with values $23.60 \pm 0.11,29.00 \pm 0.11$ and $31.03 \pm 0.14$ respectively. Catalase causes the breakdown of hydrogen peroxide and releases oxygen. The increased catalase activity showed elevated oxidative stress in the rabbit liver samples as the concentration of the chemical increased. The results coincided with [26] who expressed in their results the elevated catalase activity in the zebra fish was linked to high levels of CAT countenance, an adaptive reaction in fish body to counterbalance the generated reactive species. Similarly, [27] shared their results which reported an increase in catalase activity after 30 days of chemical exposure to rats. This increased catalase activity allows the scavenging nature of erythrocytes to convert the hydrogen peroxide to molecular oxygen and water. Likewise, [28] studied the effects of cypermethrin on freshwater mussel Unio elongatulus eucirrus; suggesting that level of catalase enzyme was raised after Cypermethrin exposure at concentrations $5,10,20,40,80$, and $160 \mu \mathrm{g} / \mathrm{L}$, for 1,24 , 48,72 , and $96 \mathrm{~h}$. The active periods of fishes had also shortened concluding that the insecticide cypermethrin has harmful effects not only on non- target aquatic arthropods and fish, but also on mollusks. [29] announced similar results that a diet containing Cypermethrin at concentration $0.02 \mathrm{mg} / \mathrm{kg} / \mathrm{day}$ induced oxidative stress and transformed oxidant-antioxidant status in the cells of not only the pregnant rats but also in their newborns.

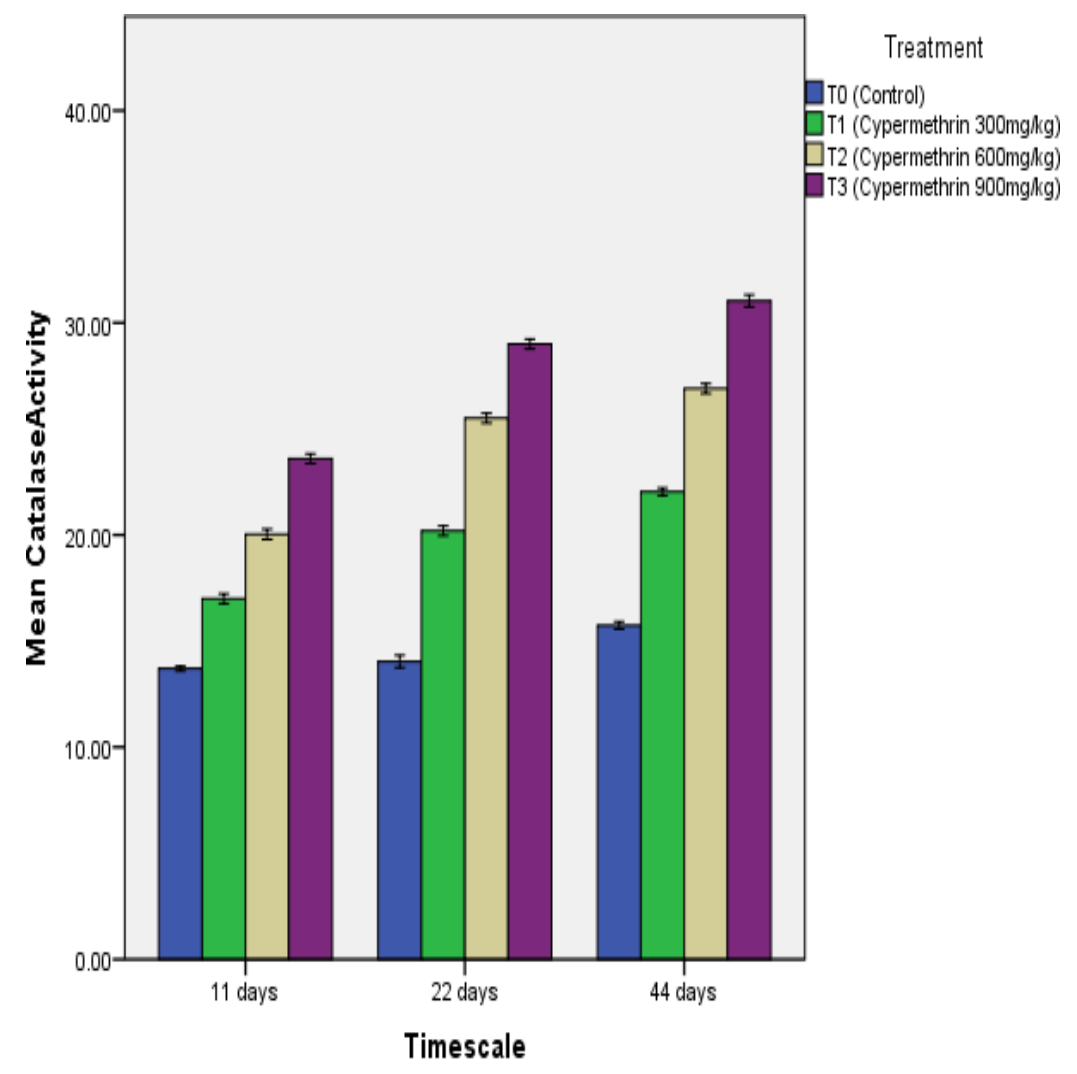

Error Bars: + /- 2 SE

Figure 9. Effect of Cypermethrin on Catalase Activity of Rabbit at the Time Scale of 11th, 22nd and 44th Day 

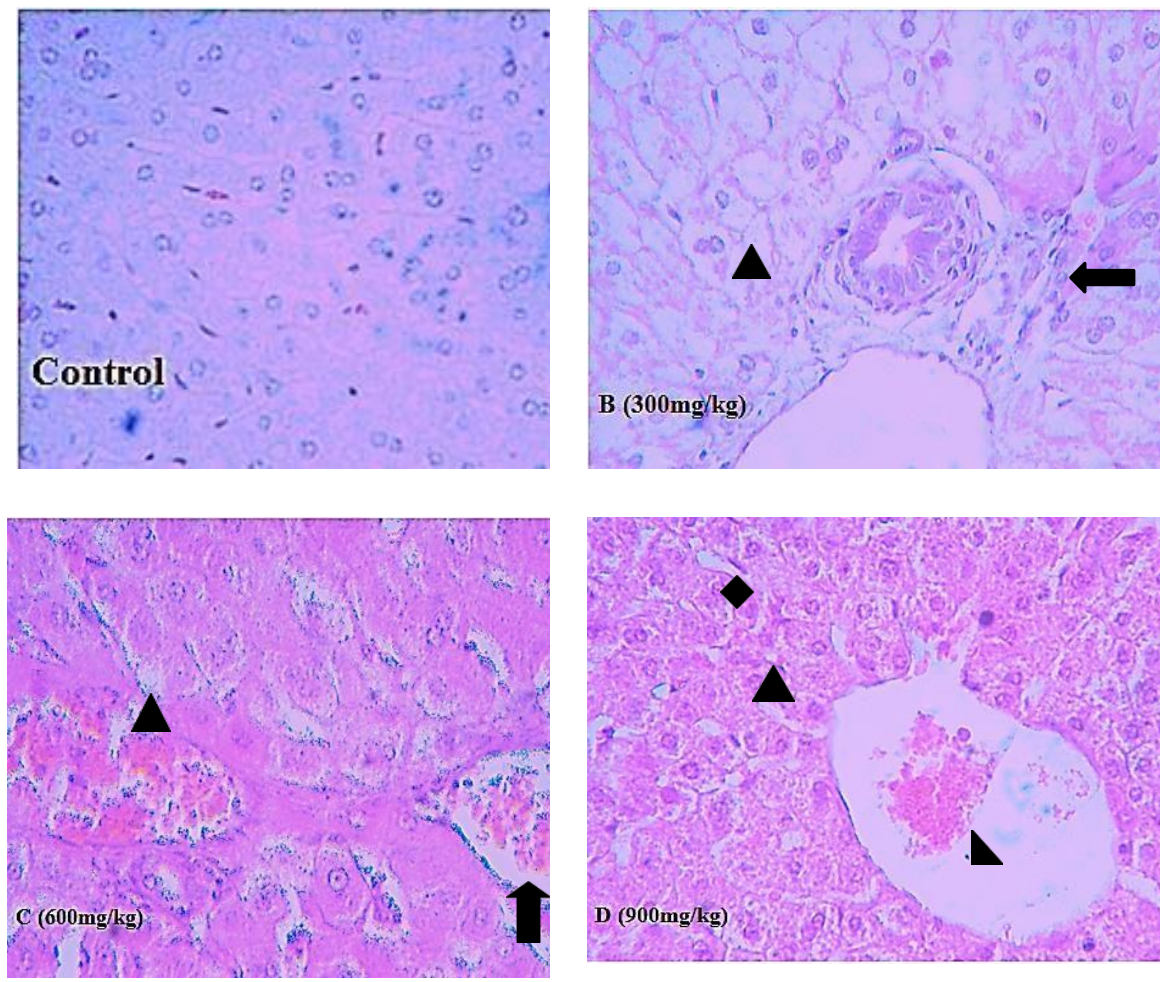

Figure 10. Histopathological changes observed upon Cypermethrin exposure at different concentrations (Control, 300, 600, $900 \mathrm{mg} / \mathrm{kg}$ ) on $11^{\text {th }}$ Day in the Rabbit Liver (x100 Magnification)
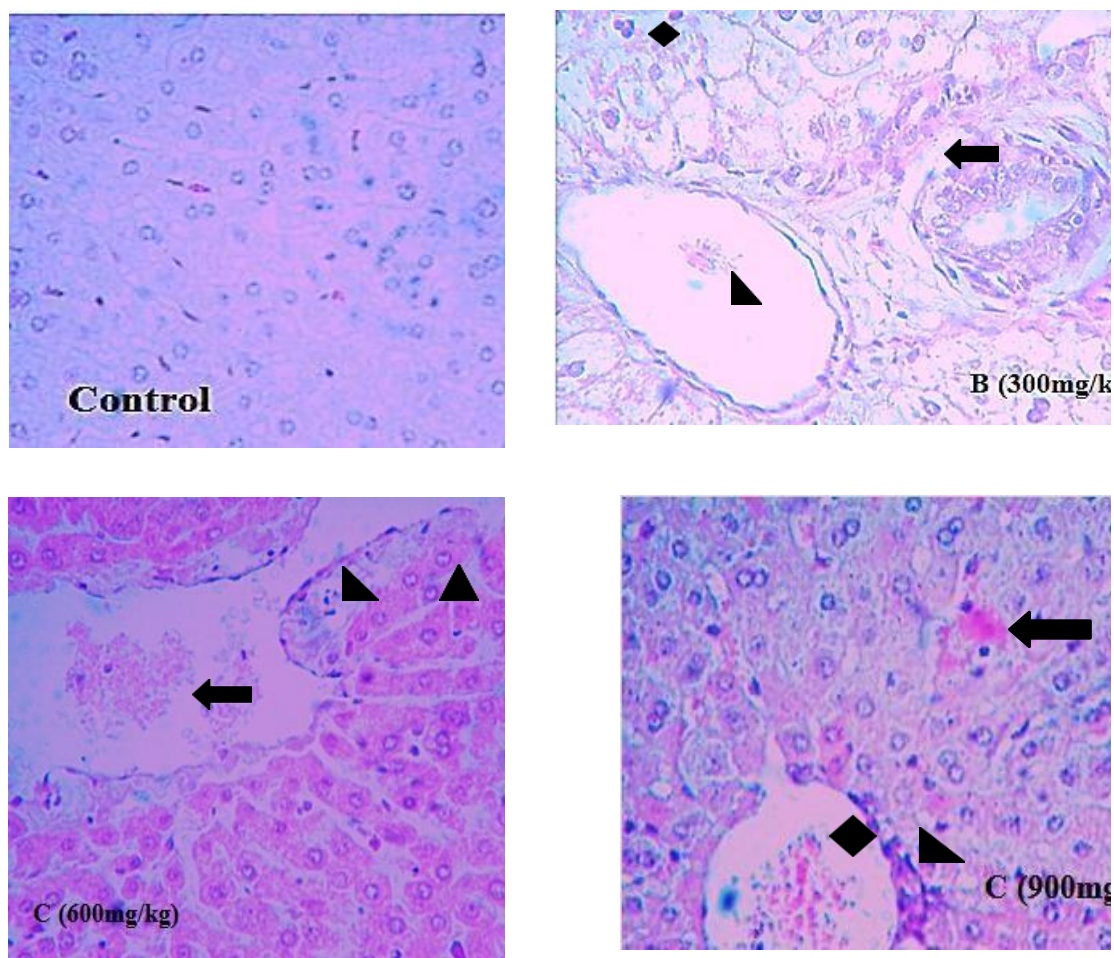

Figure 11. Concentration and Time Dependent Effects of different concentrations of Cypermethrin (Control, 300, 600, $900 \mathrm{mg} / \mathrm{kg}$ ) on $22^{\text {nd }}$ Day in the Rabbit Liver(x100 Magnification) 

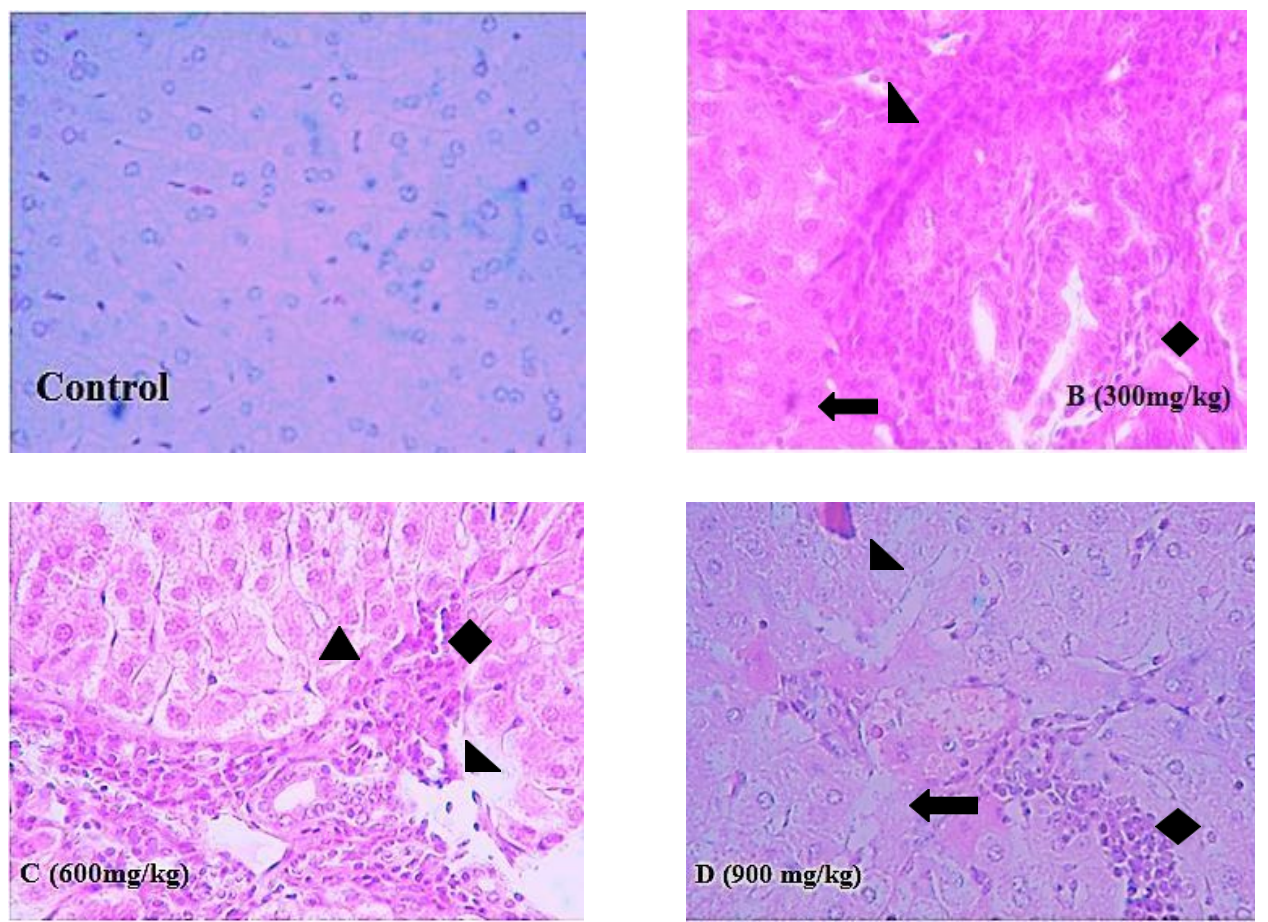

Figure 12. Concentration and Time Dependent Effects of different concentrations of Cypermethrin (Control, 300, 600, $900 \mathrm{mg} / \mathrm{kg}$ ) on 44th Day in the Rabbit Liver (x100 Magnification)

Photomicrograph sections of rabbit livers at day 11. (A) Control group showing the normal histopathological structures present in the liver. (B) Cypermethrin concentration at $300 \mathrm{mg} / \mathrm{kg}$ showing tissue lysis (diamond), infiltration (arrow) and vacuolation (triangle). (C) Cypermethrin concentration at $600 \mathrm{mg} / \mathrm{kg}$ showing congestion of cells (arrow) and tissue lysis (triangle). (D) Cypermethrin concentration at $900 \mathrm{mg} / \mathrm{kg}$ showing tissue degeneration (diamond), congestion (half triangle) and vacuolization (triangle).

Photomicrographs sections of rabbit livers at day 22. (A) Control group showing the normal histopathological structures in the liver. (B) Cypermethrin concentration at $300 \mathrm{mg} / \mathrm{kg}$ showing necrosis (diamond), infiltration (arrow) and cell coalition (half triangle). (C) Cypermethrin concentration at $600 \mathrm{mg} / \mathrm{kg}$ showing congestion of cells (arrow), hyperplasia of binary epithelium (half triangle) and vacuolization (triangle).

(D) Cypermethrin concentration at $900 \mathrm{mg} / \mathrm{kg}$ showing necrosis (arrow), congestion (diamond), vacuolation (triangle) and infiltration (half-triangle).

Photomicrographs sections of rabbit livers at day 44. (A) Control group showing the normal histolpathological structures present in the liver. (B) Cypermethrin concentration at $300 \mathrm{mg} / \mathrm{kg}$ showing infiltration (diamond), necrosis (arrow) and tissue lysis (triangle). (C) Cypermethrin concentration at $600 \mathrm{mg} / \mathrm{kg}$ showing Portal area with hepatocyte infiltration (diamond), tissue degeneration (half triangle) and vacuolation (triangle). (D) Cypermethrin concentration of $900 \mathrm{mg} / \mathrm{kg}$ showing tissue lysis (arrow), congestion (diamond) and necrosis (half triangle).

The photomicrograph sections of the rabbit livers showed significant changes that occurred in a dose dependent manner. Tissue degeneration can be seen in all treatment groups. Similarly, the incidence of infiltration, necrosis and vacuolization was a recurrent phenomenon with increasing chemical concentration. The results were similar to that of [30] who 
performed a study by using 50, 100 and $150 \mathrm{mg} / \mathrm{kg}$ of cypemrthin and concluded that Cypermethrin at various doses administered during a certain period of time generated moderate histological lesions in liver of rabbits. Likewise, [9] reported that cypermethrin in $5,7.5 \& 10$ $\mathrm{ml} / \mathrm{kg}$ doses of the body weight of mice demonstrated enlargement of the sinusoidal space, formation of vacuoles in hepatocytes, infiltration and congestion of blood vessels with hemorrhage in hepatic tissues. Similarly, [31] exposed Clarias gariepinus (Burchell, 1822) to cypermethrin concentrations $(10.05,20.10$ and $30.15 \mathrm{microg} / \mathrm{L}$ ) for ten days. They observed lesions in the liver tissues of fish characterized by the swelling of hepatocytes, pyknotic nuclei, lipoid vacuoles and necrosis. [32] expressed that at a Cypermethrin diet containing 7.5, 15 and $30 \mathrm{mg} / \mathrm{kg}$ body weight; blood congestion in hepatic vein, diffusion of some inflammatory cells, sinusoidal dilatation, diffusion of inflammatory cells, hemorrhage, distortion in the arrangement cells, hypertrophy of hepatocytes, cellular degeneration and necrosis, presence of some pyknotic cells and cytoplasmic vacuolation were observed in liver of rats.

\section{Conclusion}

The present study revealed that Cypermethrin caused a pronounced $(\mathrm{P} \leq 0.05)$ reduction in the Blood profile level in a dose dependent style of male rabbits in comparison to the control group. The tissue redox parameters showed a significant increase. Comparison between the treatment groups and the control group showed that as the concentration level of the chemical increased, so did the catalase activity. It was due to the stress caused by the chemical in the rabbit body systems their body's natural mechanism to control it. Histopathological results presented that there was noteworthy damage caused to the morphology and internal structures of the livers of rabbits in this study. As a result, it is concluded that if the use of Cypermethrin as an insecticide is continued, it will not only affect the insects and animals that eat those crops but also humans. Therefore, the need of the hour is to look for replacements to these harmful pesticides which do not pose a threat to the living organisms.

\section{Authors' contributions}

Conceived and designed the experiments: $F$ Saeed, Performed the experiment: F Saeed, Analyzed the data: F Saeed \& R Iqbal, Contributed materials/ analysis/ tools: $\mathrm{R}$ Iqbal, Wrote the paper: F Saeed.

\section{Reference}

1. Saeed T, Sawaya WN, Ahmed N \& Rajagopal S (2005). Organophosphate Residues in the Total Diet of Kuwait. Ara J Sci Engi 30(1): 17-27.

2. Shukla Y, Yadav A \& Arora A (2002). Carcinogenic and Cocarcinogenic Potential of Cypermethrin on Mouse Skin. Cancer Letters 182(1): 33-41.

3. Patel S, Pandey AK, Bajpayee M, Parmar D \& Dhawan A (2006). Cypermethrin- Induced DNA Damage in Organs and Tissues of the Mouse: Evidence from the Comet Assay. Mutat Res Genet Toxicol Environ Mutagen 607(2): 176-83.

4. Majumder R \& Kaviraj A (2017). Cypermethrin Induced Stress and Changes in Growth of Freshwater Fish Oreochromis niloticus. Int Aquat Res 9: 117-128.

5. Tao TY, Wei LZ, Yang Y, Tao Z \& Zhwo Y (2008). Effects of Alpha and Theta Cypermethrin Insecticide on Transient Outward Potassium Current in Rat Hippocampal CA3 Neurons. Pestic Biochem Phys 90.

6. Ray DE (2001). Pyrethroid Insecticides: Mechanisms of Toxicity, Systemic Poisoning Syndromes, Paresthesia, and Therapy. In: Krieger $\mathrm{R}$, editor. Handbook of Pesticide Toxicology. $3^{\text {rd }}$ Ed. Academic Press, US. pp. 1289-1303.

7. Righi D \& Palermo NJ (2003). Behavioral Effects of Type II Pyrethroid Cyhalothrin in Rats. Toxicol Appl Pharmacol 191: 167-176.

8. Sandhu HS \& Brar RS (2000). 
Textbook of Veterinary Toxicology. $1^{\text {st }}$ Ed. Kalyani Publications; New Dehli (India). pp. 225-235.

9. Mamun MAA, Illa IJ, Haque KMF \& Ferdousi Z (2014). Histological Study of the Effects of Cypermethrin on Liver and Kidney Tissues of Mice Model. Int J Pharm Biol 9(5): 121-128.

10. Sheikh N, Javed S, Asmatullah A, Ahmed KR, Abbas T \& Iqbal J (2014). Histological Changes in the Lung and Liver Tissues in Mice Exposed to Pyrethroid Inhalation. Walailak $J$ Sci Technol 11(10): 843-849.

11. Jin Y, Liu Z, Peng T \& Fu Z (2015). The Toxicity of Chlorpyrifos on the Early Life Stage of Zebrafish: A Survey on the Endpoints at Development, Locomotor Behavior, Oxidative Stress and Immunotoxicity. Fish Shellfish Immunol 43: 405-414.

12. Fang ZF, Gai H, Huang YZ, Li SG, Chen XJ, Shi JJ, Wu L, Liu A, Xu P \& Sheng HZ (2006). Rabbit embryonic stem cell line derived from fertilized, parthenogentic or somatic cell nuclear transfer embryos. Exp Cell Res 312(18): 3669-3682.

13. Shamsollahi M \& Asadi F (2014). Neurotransmitter effect of galanin on the mean plasma concentrations of growth hormone, triiodothyronine, thyroxine, and milk protein in dairy goats sannan. Endocrinology 2(3): 793801.

14. Parasuraman S, Raveendran $\mathrm{R}$ \& Kesavan R (2010). Blood sample collection in small laboratory animals. JPP 1(2): 87- 93.

15. Suvarna K, Layton C \& Bancroft JD (2012). $8^{\text {th }}$ Ed. Bancroft's Theory and Practice of Histological Techniques. Elsevier Publications; Amsterdam (Netherlands). pp. 65-68

16. Salami SA \& Raji Y (2014). Oral Ricinuscommunis oil exposure at different stages of pregnancy impairs hormonal, lipid profile and histopathology of reproductive organs in Winstar rats. J Med Plant Res 8(44):
1289-1298.

17. Hadwan MH (2018). Simple Spectrophotometric Assay for Measuring Catalase Activity in Biological Tissues. BMC Biochemistry 19(7): 1.

18. Chen X, Yin D, Hu S \& Hou Y (2004). Immunotoxicity of penta chlorophenol on macrophage immunity and IgM secretion of the crucian carp (Carassius auratus). Bull Environ Contam Toxicol 73: 153-160.

19. Dorucu M \& Girgin A (2002). The Effect of Cypermethrin on some Haematological Parameters of Cyprinus carpio. Aquaculture International 9 (2): 183-187.

20. Zorriehzahra MJ, Hassan MD, Gholizadeh M \& Saidi AA (2010). Study of some hematological and biochemical parameters of rainbow trout (Oncorhynchus mykiss) fry in western part of Mazandaran province, Iran. Iran J Fish Sci 9(1):185-198.

21. Jin Y, Zheng S, Shu L, Liu W \& Fu Z (2010). Cypermethrin has the potential to induce hepatic oxidative stress, DNA damage and apoptosis in adult zebrafish (Danio rerio). Chemosphere 82(3): 398-404

22. Slaninova A, Smutna M, Modra H \& Svobodova Z (2009). A review: oxidative stress in fish induced by pesticides. Neuro Endocrinol Lett 30: $2-12$.

23. Shah MK, Khan A, Rizvi F, Siddique M \& Rehman S (2017). Effect of Cypermethrin on ClinicoHaematological Parameters in Rabbits. Pak Vet J 27(4): 171-175

24. Yousef MI, Demerdash FM, Kamel KI \& Salhen KS (2003). Changes in some hematological and biochemical indices of rabbits induced by isoflavones and cypermethrin. Toxicology 189(3): 223234.

25. Riaz M \& Yousafzai AM (2017). Toxic Effects of Insecticides Malathion and Cypermethrin on Hematological Parameters in Blood of Male Rabbits 
(Oryctolagus cuniculus). $J$ Entomol Zool Stud 5(3): 154-158

26. Nunes MEM, Muller TE, Murussi C, Amaral AMB, Gomes JLC, Marins AT, Leitemperger J, Rodrigues CCR, Fiuza1 T.L., Costa MD., Eduardo SC., Rosemberg D.B., \&Loro V.L. (2018). Oxidative Effects of the Acute Exposure to a Pesticide Mixture of Cypermethrin and Chlorpyrifos on Carp and Zebrafish - A Comparative Study. Comp Biochem Physiol Part C Toxicol Pharmacol 207: 48-53.

27. Raina R, Verma PK, Pankaj NK \& Prawez S (2009). Induction of Oxidative Stress and Lipid. Peroxidation In Rats Chronically Exposed to Cypermethrin through Dermal Application. J Vet Sci 10(3): 257-259

28. Koprucu K, Yonar SM \& Seker E (2010). Effects of cypermethrin on antioxidant status, oxidative stress biomarkers, behavior, and mortality in the freshwater mussel Unio elongatulus eucirrus. Fish Sci 76(6): 1007-1013.

29. Hocine L, Merzouk H, Merzouk SA \& Ghorzi H (2016). The Effects of AlphaCypermethrin Exposure on Biochemical and Redox Parameters in Pregnant Rats and their Newborns. Pestic Biochem and Phys 134: 49-54.

30. Ahmad L, Khan A \& Khan MZ (2011). Cypermethrin induced biochemical and hepatorenal pathological changes in rabbits. Int J Agric Biol 13: 865-872.

31. Velmurgum B, Mathews T \& Cengiz EI (2009). Hystopathological effects of Cypermethrin in gill, liver and kidney of freshwater fish Clarias gariepinus (Burchell, 1822) and recovery after exposure. J Environ Technol 30(13): 1453-1460.

32. Yassin FH \& Hadi AA (2016). Histopathological Alterations in Liver, Kidneys and Lungs Induced by Cypermethrin Toxicity in Albino Rats. Al-Kufa Uni J Biol 8(3). 